Katarzyna Piraszewska

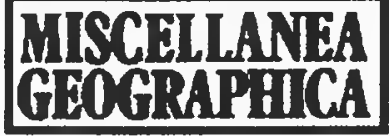

Institute of Developing Countries

E-mail: kpiraszewska@uw.edu.pl

Vol. 122006 pp. 269-275

\title{
ECONOMIC SIGNIFICANCE OF TOURISM IN THE LESSER ANTILLES
}

\begin{abstract}
The objective of the article is an attempt to assess the economic significance of tourism in chosen islands of the Lesser Antilles. Diversification of the significance of tourism in economy between particular islands of the Lesser Antilles is very extensive. The economy of islands such as the British Virgin Islands, Anguilla, Antigua and Barbuda is highly dependent on tourism. On the other hand, islands such as Martinique and Curaçao derive small profits from tourism. The tourism satellite account method was used to show to what a degree each of the Lesser Antilles islands is dependent on tourism and what profits are derived from it. The account considers both direct and indirect outlays on tourism. The selected countries are divided into groups according to the intensity of tourism, the size of the GDP generated per one inhabitant as well as the share of employment in tourism per total employment. A group of countries and dependent territories deriving greater and lesser economic benefits from tourism than might appear from the intensity of tourism is identified.
\end{abstract}

Key words: tourism, the Lesser Antilles, tourism satellite account

\section{INTRODUCTION}

The objective of the is article is an attempt to assess the economic significance of tourism in chosen Lesser Antilles islands. A significant element is the assessment of the share of tourism in generating the Gross Domestic Product, employment and export. Diversity between particular Lesser Antilles islands is very extensive. There are islands such as Anguilla, Antigua, Barbuda and Barbados which are highly dependent on tourism and islands such as Martinique, Trinidad and Tobago which derive small profits from tourism. The tourism satellite account method is used to show to what a degree each of the Lesser Antilles islands is dependent on tourism and what profits are derived from it. Such an account takes under consideration outlays directly related to tourism, e.g. expenditures on hotels, restaurants, travel agencies, transport, as well as travelers' expenditures on goods and services not directly related to tourism, e.g. expenditures on food, beverages, car rental, gasoline, insurance (OECD, 2001, p.1-5). The tourism satellite account is a method which is the most objective and comprehensive and 
should show the significance of tourism in the economy of chosen countries and dependent territories of the Lesser Antilles (WTTC, 2005, p. 3-38).

\section{THE TOURISM SATELLITE ACCOUNT METHOD}

The satellite account is used as a comprehensive instrument for the measurement of economic effects of tourism. The approach of the preparation of the tourism satellite account by WTTC is based on an econometric model built on the basis of interbranch transmissions, describing the influence of expenditures on basic econometric indices. This model is based on data published by particular countries and by simulation, it illustrates their influence on the economy. In the WTTC methodology, the demand side of tourism comprises household expenditures, expenditures of enterprises and institutions on business travel, central government and local government expenditures on partial funding of services aimed at visitors, visitors' foreign expenditures, government expenditures on activities supporting tourism ${ }^{1}$, investment expenditures on infrastructure used by the visitors, export of goods destined for those going abroad ${ }^{2}$ (Dziedzic E., 2003, p. 43-52). The tourism satellite account method allows to assess the size of the Gross Domestic Product and employment in the tourist industry as well as the broader scope of tourism economy. Employment in the tourism industry usually comprises jobs which require direct contact with travelers, e.g. airlines, hotels, car rental, restaurants, retail commerce, entertainment, etc. Employment in tourism economy comprises employment in the tourist industry and jobs not directly related to tourism but indirectly existing thanks due to tourism. It should be emphasized that tourism is a labour-intensive sector, characterized by a high coefficient of job creation in comparison with other sectors of the economy (World Tourism Organization, 1999, p. 47).

\section{ASSESSMENT OF ECONOMIC SIGNIFICANCE OF TOURISM FOR CHOSEN LESSER ANTILLES ISLANDS}

Due to the availability of data on the tourism satellite account fifteen islands, independent countries as well as dependent territories, were selected. Among the independent countries which were analyzed are Antigua and Barbuda, Barbados, Grenada, Saint Kitts and Nevis, Saint Lucia, Saint Vincent and the Grenadines, Trinidad and Tobago. The dependent territories included in the analysis are the American and British Virgin Islands, Anguilla, Aruba, Curaçao, Dominica, Guadeloupe and Martinique. Among the chosen island territories the largest is Trinidad and Tobago with an area

\footnotetext{
I e.g. promotion, sanitary control, airline transport.

2 e.g. gasoline, clothing, souvenirs.
} 
of $5.128 \mathrm{~km}^{2}$ and 1. 309.000 inhabitants. The smallest is Anguilla with an area of $91 \mathrm{~km}^{2}$ and 13.800 inhabitants.

In 2001 , over $10.5 \mathrm{ml}$ foreign tourists visited the Lesser Antilles for one day or more. The American Virgin Islands (24.4\%) and Aruba (11.2\%) had the greatest share of visitors. The American Virgin Islands, which in 2001 were visited by 592.000 tourists and 1.971 .000 one day visitors, decisively are the favorite in the share of tourism in the economy and the percentage of visitors.

In the analysis, selected islands were grouped according to intensity of tourism ${ }^{3}$ into three groups, i.e. islands with large, medium and small intensity of tourism. The tourism intensity index takes into consideration the number of foreign tourists as well as one day visitors. In the Lesser Antilles, one may observe a large diversity of tourism. In the British Virgin Islands, during the year, the number of tourists and one day visitors outnumbers 23 times the number of permanent residents. The tourism intensity index is 2356. However, for Trinidad and Tobago this index is 36 , which means that per 100 island residents there are 36 foreign tourists and one day visitors.

Table 1.

Number of inhabitants, area, tourism and tourism intensity in chosen island territories of the Lesser Antilles in 2001

\begin{tabular}{|r|l|r|r|r|r|}
\hline No. & \multicolumn{1}{|c|}{$\begin{array}{c}\text { Chosen islands } \\
\text { of the Lesser Antilles }\end{array}$} & $\begin{array}{c}\text { Number of } \\
\text { inhabitants* }\end{array}$ & $\begin{array}{c}\text { Area } \\
\left(\text { in } \mathrm{km}^{2}\right)^{* *}\end{array}$ & $\begin{array}{c}\text { Number of foreign tourists } \\
\text { and one day visitors } \\
\text { (in thousands })^{* * *}\end{array}$ & $\begin{array}{c}\text { Intensity of } \\
\text { tourism }\end{array}$ \\
\hline 1 & Amer. Virgin Islands & 108775 & 342 & 2563 & 2356 \\
\hline 2 & Anguilla & 13800 & 91 & 105 & 761 \\
\hline 3 & Antigua and Barbuda & 68490 & 440 & 666 & 972 \\
\hline 4 & Aruba & 268190 & 431 & 1178 & 1654 \\
\hline 5 & Barbados & 22187 & 150 & 1035 & 386 \\
\hline 6 & British Virgin Islands & 150000 & 544 & 535 & 2411 \\
\hline 7 & Curacao & 71870 & 750 & 505 & 337 \\
\hline 8 & Dominica & 100410 & 344 & 276 & 384 \\
\hline 9 & Grenada & 444515 & 1800 & 278 & 277 \\
\hline 10 & Guadeloupe & 429510 & 1080 & 882 & 198 \\
\hline 11 & Martinique & 38836 & 167 & 663 & 154 \\
\hline 12 & Saint Kitts and Nevis & 156700 & 616 & 333 & 857 \\
\hline 13 & Saint Lucia & 115880 & 388 & 746 & 476 \\
\hline 14 & Saint Vincent and & 1309610 & 5128 & 254 & 219 \\
\hline 15 & Trinidad and Tobago & $130 n a d i n e s$ & 465 & 36 \\
\hline
\end{tabular}

Source: own elaboration on the basis of

* Eurostat

** World Tourism Organization, 2000, Compendium of Tourism Statistics 1994-1998, Madrid

*** World Tourism Organization, 2003, Compendium of Tourism statistics, Madrid, (data for 2001), Antigua and Barbuda - 2000,

$* * * *$ Tourists and one day visitors/number of inhabitants $\mathrm{x} 100$

\footnotetext{
${ }^{3}$ Tourism intensity index $=$ (number of tourists and one day visitors/ number of residents) $/ 100$
} 
Island territories with small tourism (index below 300) comprise the earlier mentioned Trinidad and Tobago, Martinique, Guadeloupe, Saint Vincent and the Grenadines, Grenada. The medium tourist intensity island group (indexr between 300 and 1000) comprises Curaçao, Dominica, Barbados, Saint Lucia, Anguilla, Saint Kitts and Nevis, Antigua and Barbuda. However, territories such as Aruba, American and British Virgin Islands are characterised by large tourist intensity (indicator above 1.000).

A large number of tourists and one day visitors stems, among other factors, from a large number of circle cruise passengers. In 2001, among the analysed nations and dependent territories of the Lesser Antilles, the greatest number of circle cruise passengers was registered in the American Virgin Islands (1.981.000), Barbados (528.000), Saint Lucia (490.000) and Aruba (487.000). The least number of circle cruise passengers (fewer than 200.000 persons) arrived in Saint Vincent and the Grenadines, Grenada and Trinidad and Tobago ${ }^{4}$.

In the area of economy, the most dependent on tourism are island territories where the GDP generated by tourism economy is above $50 \%$, i.e. the British Virgin Islands (95.2\%), Antigua and Barbuda (77.7\%), Anguilla (75.9\%), Aruba (59.8\%). The least dependent, however, (GDP generated by tourism economy is below 10\%) are Martinique and Curaçao.

Countries and dependent territories are also grouped according to the GDP values generated by tourism economy and the number employed in tourism economy per the resident number. Countries with a large GDP value generated by tourism economy per one inhabitant (above 10 thousand USD) are Aruba and the British and American Virgin Islands, with a medium size value (from 1.000 to $10.000 \mathrm{USD} / \mathrm{inh}$ abitant) are Antigua and Barbuda, Anguilla, Barbados, Saint Kitts and Nevis, Saint Lucia, Guadeloupe, Martinique and Grenada, and those with a small value (below 1.000 USD/inhabitant) are Saint Vincent and the Grenadines, Dominica, Curaçao, Trinidad and Tobago. However, countries and dependent territories with a large number of employees in tourism economy in relation to the total number of employed (more than 50 per 100 employees) are Antigua and Barbuda, the British Virgin Islands, Anguilla, Aruba and Barbados, with a medium number of employees (from 25 to 50) are Saint Lucia, the American Virgin Islands, Saint Vincent and the Grenadines, Saint Kitts and Nevis, Grenada and Guadeloupe, and a small number of employees (fewer than 25) are Dominica, Trinidad and Tobago, Martinique and Curaçao.

Thanks to grouping the island territories by intensity of tourism and data on the tourism satellite account, the GDP value generated by tourism economy and the number of employees in tourism per the total number of employees, it is possible to determine:

\footnotetext{
${ }^{4}$ For Anguilla there are no data on the number of circle cruise passengers visiting the island.
} 
Table 2.

Tourism sattelite account - share of tourism economy and industry in GDP and employment in 2001

\begin{tabular}{|c|c|c|c|c|c|}
\hline No. & $\begin{array}{l}\text { Chosen Lesser } \\
\text { Antilles Islands }\end{array}$ & $\begin{array}{l}\text { Share of tourism } \\
\text { industry in GDP } \\
\text { (in \%) }\end{array}$ & $\begin{array}{l}\text { Share of tourism } \\
\text { economy in GDP } \\
\text { (in \%) }\end{array}$ & $\begin{array}{c}\text { Share of tourism } \\
\text { industry } \\
\text { employees per } \\
\text { total employment } \\
\text { (in \%) }\end{array}$ & \begin{tabular}{|c|} 
Share of tourism \\
economy employees \\
per total \\
employment \\
(in \%)
\end{tabular} \\
\hline 1 & $\begin{array}{l}\text { Amer. Virgin } \\
\text { Islands }\end{array}$ & 10.2 & 35.0 & 14.3 & 42.0 \\
\hline 2 & Anguilla & 29.1 & 75.9 & 33.7 & 84.3 \\
\hline 3 & $\begin{array}{l}\text { Antigua and } \\
\text { Barbuda }\end{array}$ & 24.0 & 77.7 & 33.6 & 94.8 \\
\hline 4 & Aruba & 20.8 & 59.8 & 29.1 & 76.0 \\
\hline 5 & Barbados & 12.8 & 42.9 & 16.1 & 47.8 \\
\hline 6 & $\begin{array}{l}\text { British Virgin } \\
\text { Islands }\end{array}$ & 37.4 & 95.2 & 38.3 & 95.0 \\
\hline 7 & Curacao & 2.1 & 6.9 & 2.9 & 7.9 \\
\hline 8 & Dominica & 8.5 & 24.6 & 7.9 & 23.4 \\
\hline 9 & Grenada & 8.0 & 25.4 & 7.9 & 24.0 \\
\hline 10 & Guadeloupe & 8.7 & 27.1 & 8.6 & 27.1 \\
\hline 11 & Martinique & 2.2 & 9.3 & 2.8 & 9.9 \\
\hline 12 & $\begin{array}{l}\text { Saint Kitts and } \\
\text { Nevis }\end{array}$ & 8.0 & 28.8 & 9.0 & 29.3 \\
\hline 13 & Saint Lucia & 15.5 & 44.8 & 16.4 & 45.1 \\
\hline 14 & $\begin{array}{l}\text { Saint Vincent } \\
\text { and the } \\
\text { Grenadines }\end{array}$ & 10.1 & 32.0 & 9.4 & 28.7 \\
\hline 15 & $\begin{array}{l}\text { Trinidad and } \\
\text { Tobago }\end{array}$ & 2.5 & 10.7 & 2.8 & 10.5 \\
\hline
\end{tabular}

Source: World Travel and Tourism Council, 2004, Travel and Tourism forging ahead - The 2004 Travel and Tourism Economic Research, Oxford

A - group of countries and dependent territories which derive greater economic benefits from tourism than it might be indicated by the intensity of tourism:

These are countries and dependent territories which are characterised by:

- a greater GDP value generated by the tourism economy per one inhabitant in relation to the intensity of tourism (Grenada, Guadeloupe, Martinique),

- a greater share of employees in tourism economy (per the total number of employees) in relation to the intensity of tourism (Anguilla, Antigua and Barbuda, Barbados, Grenada, Guadeloupe, Saint Vincent and the Grenadines). 
B - group of countries and dependent territories deriving smaller economic benefits from tourism than it might be indicated by the intensity of tourism; by:

These are countries and dependent territories which are characterised

- a smaller GDP value generated by tourism economy per one inhabitant in relation to the intensity of tourism - Curaçao, Dominica,

- a smaller share of employees in tourism economy (per the total number of employees) in relationship to the intensity of tourism - the American Virgin Islands, Curaçao, Dominica.

As might be expected, the interrelation between the intensity of tourism and the GDP value generated per one inhabitant by tourism economy measured by Pearson's correlation coefficient is high. The value of the correlation coefficient between these two characteristics is 0.907 . This means that the greater intensity of tourism leads to a greater GDP value, stemming from tourism economy per one inhabitant. The interrelation between both the intensity of tourism and the number of employees in tourism economy and the total employment measured by Pearson's correlation coefficient is average. The correlation value between these two characteristics is 0.601 .

The diversity between the size of receipts from tourism may be caused, among others, by different stay duration of foreign tourists or the mean value of their outlays. Among islands for which it is published by the WTO, long-term holidays dominate and the average stay of foreign tourists oscillates between 7 and 13 days. In 2001, the average stay in Grenada was 7.23 days, in Aruba - 8 days, in Anguilla - 8.5 days, in Curaçao - 8.5 days, in Saint Kitts and Nevis - 8.7 days, in the British Virgin Islands - 9.9 days, in Barbados - 10.2 days, in Saint Vincent and the Grenadines - 10.6 days, in Martinique - 13.2 days (WTO, 2003 p. 8-215). The average tourist expenditures (measured in USD per 1 tourist) in the island territories of the Lesser Antilles are very diversified. They oscillate between 512 USD for Grenada (data for 2001) to 1.270 USD for Anguilla. Among countries with small expenditures (less than 1000 USD per person) are Dominica, Guadeloupe, Martinique, Saint Kitts and Nevis, Saint Lucia, Trinidad and Tobago. Large average tourist expenditures (exceeding 1000 USD per one tourist) are recorded in Anguilla, Antigua and Barbuda, Aruba, Barbados, the American and British Virgin Islands, Curaçao, Saint Vincent and the Grenadines.

Most island territories of the Lesser Antilles, with the exception of Trinidad and Tobago ${ }^{5}$, have a negative trade exchange balance. Numerous also have a negative balance of trade exchange in relation to tourism. On the export side, taken into account are the expenditures of foreign tourists incurred within the territory of the country being visited. On the other hand, import comprises, among others, goods and services imported from abroad for the purpose of rendering services on behalf of tourists. Among countries and

${ }^{5}$ Lack of data for Curacao and the American Virgin Islands 
dependent territories with a negative balance (the predominance of import over export of tourism) are, among others, Curaçao and Martinique.

In the Lesser Antilles tourism, in a direct manner, gives employment to 1.203.000 inhabitants. However, taking into consideration jobs indirectly related to tourism, it generates jobs for 3.616 .000 inhabitants. The share of those employed in tourism economy varies between $7.9 \%$ for Curaçao to $95 \%$ for the British Virgin Islands. Barbados is characterised by the highest number of employees in the tourism economy in relation to the intensity of tourism which undoubtedly is related to the average length of stay on this island (10.2 days). On the other hand, the American Virgin Islands are characterised by the lowest index of employment in relation to the intensity of tourism. This may be explained by the significant number of one day visitors who, for the most part, are passengers of circle cruises.

\section{CONCLUSIONS}

The Lesser Antilles are a region of highly diversified tourism as well as diversified significance of tourism to the economy. Two groups of countries and dependent territories deriving greater and smaller economic benefits from tourism in regard to tourist intensity have been identified. In regard to the GDP value as well as employment determined by the tourism satellite account method, greater benefits, as compared to other countries and dependent territories of the Lesser Antilles, are derived by Grenada and smaller benefits are derived by Dominica and Curaçao. It may be assumed that this is caused by the number of circle cruise passengers, the average length of stay of tourists and the dominant type of tourism.

\section{REFERENCES}

Dziedzic E., 2003, Rachunek satelitarny jako narzędzie mierzenia efektów ekonomicznych turystyk (The satellite account as instrument for measuring economic effects of tourism; in Polish], Akademia Ekonomiczna w Poznaniu, Wydawnictwo Naukowe PWN, Warszawa

OECD, 2001, Tourism Satellite Account: Recommended Methological Framework, New York

World Tourism Organization, 1999, Tourism Challenges in the 21st century, Human Resource Development in Asia and Pacific, Madrid

World Tourism Organization, 2000, Compendium of Tourism Statistics 1994-1998, Madrid

World Tourism Organization, 2003, Compendium of Tourism Statistics, Madrid

World Travel and Tourism Council, 2004, Travel and Tourism forging ahead - The 2004 Travel and Tourism Economic Research, Oxford

World Travel and Tourism Council, 2005, Caribbean, Travel and Tourism - sowing the seeds of growth, Oxford 